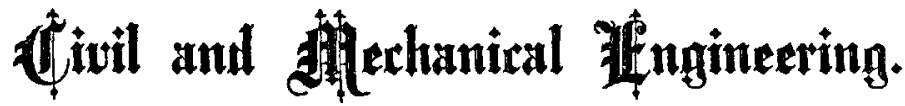

\section{THE STEAM BOILER EXPLOSION AT THE KEYSTONE MILLS, TWENTY- FIFTH AND CALLOWHILL STREETS, PHILADELPHIA.}

[It was for many years the usual practice of the JoURNAL to record the simple facts attending the explosions of steam boilers in Philadelphia, or its immediate vicinity. In accordance with this, the following communication is published. It is proposed to complete the record by similar descriptions of other explosions which have occurred within the past six or eight years.]

On Friday, May 8th, 1874, shortly after three Y.M., an explosion of one of the six plain cylinder boilers, which furnished the steampower for the Keystone Mills, took place. There were three pairs of boilers set in couples, each boiler being 30 feet long and 36 inches in diameter; the pairs having independent setting and all the appliances provided by law. Generally two pairs (or sets) were amply sufficient to give steam to drive the mills, but a few days prior to the explosion, some coal of bad quality was used, and it was found necessary to fire up the third set.

This third set had been standing idle for some time previously. In January, (1874), they had been put in condition for use in an emergency, having been then examined by the boiler inspector for an insurance company, and one of the two repaired at his suggestion.

On the afternoon of the explosion, the engineer noticed a leak in the repaired boiler, (which was the outside one of the third set), and immediately hauled the fire from this set, shut off the connections to the other two sets, and was in the act of attaching a water pipe to the blow off cock when the boiler exploded. The parting was at the third row of rivets, and the front head with two rings of the shell was projected nearly horizontally, about 150 feet, passing, in its course, through the board enclosure of a shed. The back end, with about 25 feet of the shell, was driven in the opposite direction (also horizontally) passing through a coal pile some eight fect in thickness, and stopping in a second heap of coal about 100 feet from the setting, the resistance of the coal retarding and finally arresting its flight.

VoI. LXX.-ThIRd SERIEs.-No. 4. --OctoBER, 1875. 
The engineer, Hugh Sweeney, and a boy, Thos. Ivan Devor, were acalded and otherwise injured; both died the following day. There were narrow escapes, but no other injuries of person. The fracture followed the seam all around, partly in the line of rivet holes and partly on the line of caulking. At one place on the underside on the line of caulking, there was an old crack, with well coated surface, 17" to $19^{\prime \prime}$ long - a fracture evidently of long existence. The iron of the shell at the place of rupture had worn a little, perhaps a number of the gauge (that is, from No. 4, its original thickness, to No. 5.) The inspection had located the defect of the boiler at this seam, and there was a new patch along a part of it; the rent happening in the old sheet along the rivet holes, which joined on the new patch. As stated, 17" to $19^{\prime \prime}$ of old crack was disclosed. This weakness, together with the probable injury to the old sheet, from drifting out rivets and stretching the holes in putting in new ones, was sufficient to attribute want of strength as the cause of the disaster. The repairs had evidently been injudiciously made, and the boiler imperfectly examined on their supposed completion.

The experience of the writer has lead him to conclude that taking in consideration all the abuses of boilers in service, the average duration of boilers of good construction is about ten years. This boiler had been over twenty years in use, and its age should have called for elose scrutiny when repairs were made.

Wm. Barnet LeVan, Engineer.

\title{
STAND-PIPE FOR BLOOMINGTON, ILL.
}

\author{
By H. M. P. Birkinbine.
}

In constructing water-works for western cities, it is frequently impossible to have a reservoir, for want of the necessary elevated ground to place it upon. Many of the cities, have, therefore, been contented to adopt the direct supply plan; that is, pumping directly into the distributing mains, the plan adopted by Peter Morice, in the works built for supplying the city of London, at London Bridge, in 1582. The imperfections of such a system are apparent, the supply 